\title{
TEKNIK KULTUR Chlorella sp. SKALA LABORATORIUM DAN INTERMEDIET DI BALAI PERIKANAN BUDIDAYA AIR PAYAU (BPBAP) SITUBONDO JAWA TIMUR
}

\section{The Culture Technique of Chlorella sp. in Laboratory scale and Intermediates at the "Balai Perikanan Budidaya Air Payau Situbondo" East Java}

\author{
Afif Mufidah $^{1} *$ Agustono $^{2}$, Sudarno $^{2}$ dan Daruti Dinda Nindarwi ${ }^{2}$. \\ ${ }^{1}$ Program Studi Budidaya Perairan, Fakultas Perikanan dan Kelautan, Universitas Airlangga, Surabaya \\ ${ }^{2}$ Departemen Manajemen Kesehatan Ikan dan Budidaya Perairan, Fakultas Perikanan dan Kelautan, Universitas \\ Airlangga, Surabaya \\ *afif.mufidah-2014@fpk.unair.ac.id
}

\begin{abstract}
Abstrak
Mikroalga adalah tumbuhan tingkat rendah yang memiliki klorofil untuk melakukan fotosintesis (Rismiarti dkk., 2016). Beberapa spesies mikroalga di alam merupakan pakan alami bagi ikan dan udang. Pakan alami menjadi sumber nutrisi penting pada stadium awal perkembangan organisme. Salah satu pakan alami yang digunakan untuk budidaya ikan yaitu Chlorella sp.. Chlorella sp. memiliki kandungan nutrisi protein sebesar 51-58\%, minyak sebesar 28-32\%, karbohidrat $12-17 \%$, lemak 14-22\%, dan asam nukleat 4-5\% (Rachmaniah dkk., 2010).Salah satu cara untuk memperoleh biakan murni Chlorella sp. agar dapat memenuhi ketersediaan pakan alami dalam jumlah yang cukup, berkesinambungan dan tepat waktu adalah dengan adanya tindakan kultur. Praktek Kerja Lapang ini dilaksanakan di Balai Perikanan Budidaya Air Payau (BPBAP) Situbondo, Jawa Timur pada tanggal 23 Januari sampai tanggal 23 Februari 2017. Tujuan praktek kerja lapang ini adalah untuk mendapatkan pengetahuan tentang teknik kultur Chlorella sp. skala laboratorium dan intermediet. Metode kerja yang digunakan yaitu metode deskriptif. Metode tersebut meliputi wawancara, observasi, dan partisipasi aktif selama proses kegiatan kultur Chlorella sp. skala laboratorium dan intermediet. Data yang terkumpul terdiri atas data primer dan sekunder. Kegiatan kultur Chlorella sp. skala laboratorium dilakukan dengan metode kultur bertingkat di dalam ruangan (indoor). Kultur Chlorella sp. dimulai dengan persiapan alat dan bahan (sterilisasi), pembuatan pupuk Walne dan vitamin, isolasi Chlorella sp. pada Petridish (media agar), kultur pada test tube $10 \mathrm{ml}$, kultur pada Erlenmeyer $250 \mathrm{ml}$, kultur pada Bottle glass 3 liter, dan kultur pada Carboy 10 liter. Kegiatan kultur Chlorella sp. skala intermediet dilakukan dimulai dengan persiapan alat dan bahan (sterilisasi), pemberian bibit Chlorella sp. yang berasal dari kultur murni skala laboratorium. Pemeliharaan Chlorella $\mathrm{sp}$. dilakukan selama kurang lebih 5 hari yang mencapai fase eksponensial pada hari ke 4. Pemanenan dilakukan dengan metode flokulan kimia menggunakan $\mathrm{NaOH}$. Kendala yang terdapat dalam teknik kultur Chlorella sp. adalah media kultur yang tidak bebas dari kontaminan, kepadatan awal yang tidak optimal, dan kondisi lingkungan yang tidak baik. Kondisi lingkungan yang tidak baik seperti kualitas air yang tidak sesuai dengan habitat Chlorella sp. dan kondisi cuaca yang fluktuatif akibat musim pancaroba yang mempengaruhi intensitas cahaya pada kultur Chlorella sp. skala intermediet.
\end{abstract}

Kata kunci: Chlorella sp., Kultur, Skala Laboratorium dan Skala Intermediet

\begin{abstract}
Microalgae are low-level plants that have chlorophyll to photosynthesize (Rismiarti dkk., 2016). Some species of microalgae in nature is a natural feed for fish and shrimp. Natural feed becomes a source of essential nutrients in the early stages of development of the organism. One of the natural feed which is used for fish farming, namely Chlorella sp.. Chlorella sp. it has nuttritional content of protein by 51-58\%, oil by $28-32 \%$, carbohydrate $12-17 \%$, fat $14-22 \%$, and nucleic acids $4-5 \%$ (Rachmaniah dkk., 2010). One of the ways to obtain pure cultures of Chlorella sp. in order to meet the availability of natural feed in sufficient quantities, continuous, and timely is the presence of cultural action. This internship itself was held in Balai Perikanan Budidaya Air Payau (BPBAP) Situbondo, Jawa Timur, on January 23 until February 23, 2017. The purpose of this Field Work Practice is to know and to obtain additional knowledge about the culture techniques Chlorella sp. in laboratory scale and intermediates. The method used during the internship was the descriptive method. The descriptive method included an interview, an observation, and an active participation during culture of Chlorella sp. process in laboratory scale in intermediates. The collected data from that method were the primary data and the secondary data. Culture activities Chlorella sp. laboratory scale at the Balai Perikanan Budidaya Air Payau
\end{abstract}


Situbondo conducted using batch culture method in indoors. Chlorella sp. culture begins with the preparation of tools and materials (sterilization), make Walne fertilizer and vitamins, Chlorella sp. isolation on Petridish (agarose medium), the culture at test tube $10 \mathrm{ml}$, the culture at Erlenmeyer $250 \mathrm{ml}$, the culture at Bottle glass 3 liter and, the culture at Carboy 10 liter. Culture activities Chlorella sp. intermediates scale begins with the preparation of tools and materials (sterilization), the inclusion of seed Chlorella sp. derived from pure culture laboratory scale. Chlorella sp. maintenance for approximately 5 days to reach the exponential phase on day 4 . Harvesting is done by the method of chemical flocculants using $\mathrm{NaOH}$. The obstacles found during culture technique of Chlorella sp. is a culture medium which is not free of contaminants, which are not optimal initial density, and environmental conditios are not good. Environmental conditions are not as good as the quality of water that does not comply with Chlorella sp. habitat and the fluctuative weather condition due to the transition season which impacts to the intensity of light in cultured Chlorella sp. in intermediates scale.

Keywords: Chlorella sp., Culture, Laboratory Scale, and Intermediates Scale

\section{PENDAHULUAN}

Mikroalga adalah tumbuhan tingkat rendah yang memiliki klorofil untuk melakukan fotosintesis (Rismiarti dkk., 2016). Beberapa spesies mikroalga di alam merupakan pakan alami bagi ikan dan udang. Pakan alami merupakan pakan yang baik untuk kegiatan pemeliharaan ikan karena diketahui memiliki kandungan nutrisi lebih tinggi dibandingkan pakan buatan. Pakan alami menjadi sumber nutrisi penting pada stadium awal perkembangan organisme. Salah satu pakan alami yang digunakan untuk budidaya ikan yaitu Chlorella sp..

Chlorella sp. merupakan salah satu jenis fitoplankton yang sering dimanfaatkan dalam pembenihan organisme laut di hampir semua hatchery sebagai pakan yang langsung diberikan pada benih ikan atau udang maupun sebagai tidak langsung dengan diberikan ke zooplankton terlebih dahulu yang selanjutnya zooplankton diberikan sebagai pakan pada benih ikan atau udang (Chilmawati dan Suminto, 2008). Chlorella sp. memiliki kandungan nutrisi protein sebesar 51-58\% minyak sebesar $28-32 \%$, karbohidrat $12-17 \%$, lemak 14$22 \%$, dan asam nukleat $4-5 \%$ (Rachmaniah dkk., 2010).

Chlorella sp. tumbuh pada media yang mengandung cukup unsur hara. Unsur hara yang diperlukan Chlorella sp. dalam jumlah besar adalah karbon (C), nitrogen $(\mathrm{N})$, fosfor $(\mathrm{P})$, sulfur $(\mathrm{S})$, natrium $(\mathrm{Na})$, magnesium $(\mathrm{Mg})$, dan kalsium $(\mathrm{Ca})$. Unsur hara yang dibutuhkan dalam jumlah relatif sedikit adalah besi $(\mathrm{Fe})$, tembaga $(\mathrm{Cu})$, mangan $(\mathrm{Mn})$, seng $(\mathrm{Zn})$, silikon (Si), boron (B), molibdenum (Mo), vanadium (V) dan kobalt (Co) (Chumadi, dkk. 1992). Chlorella sp. tumbuh optimal pada suhu $25^{\circ} \mathrm{C}$, pH 7-8, dan salinitas 25 ppt.

Target produksi pada kegiatan budidaya ikan akan lebih mudah tercapai dengan melakukan kultur fitoplankton. Kultur fitoplankton dilakukan dalam skala laboratorium, skala intermediet, dan skala massal. Kultur fitoplankton ini bertujuan untuk memperoleh biakan murni agar dapat memenuhi ketersediaan pakan alami dalam jumlah yang cukup, berkesinambungan dan tepat waktu (Sari, 2012).

Tujuan pelaksanaan Praktek Kerja Lapang (PKL) ini adalah untuk mengetahui teknik kultur Chlorella sp. dalam skala laboratorium dan skala intermediet di Balai Perikanan Budidaya Air Payau Situbondo serta kendala yang ada dalam proses kultur.

\section{METODOLOGI}

\section{Waktu dan Tempat}

Kegiatan Praktek Kerja Lapang (PKL) Praktek Kerja Lapang ini dilaksanakan di Balai Perikanan Budidaya Air Payau (BPBAP) Situbondo, Jawa Timur. Kegiatan Praktek Kerja Lapang ini dilaksanakan mulai tanggal 23 Januari - 23 Februari 2017.

\section{Metode Penelitian}

Metode kerja yang digunakan yaitu metode deskriptif. Metode tersebut meli- 
puti wawancara, observasi, dan partisipasi aktif selama proses kegiatan kultur Chlorella sp. skala laboratorium dan intermediet. Data yang terkumpul terdiri atas data primer dan sekunder.

\section{HASIL DAN PEMBAHASAN}

Balai Perikanan Budidaya Air Payau (BPBAP) Situbondo Jawa Timur merupakan Unit Pelaksana Teknis (UPT) Kementerian Kelautan dan Perikanan yang mempunyai tugas melaksanakan penerapan teknik pembenihan pembudidayaan ikan air payau serta pelestarian induk atau benih ikan dan lingkungan. Sejalan dengan visi dan misi Kementerian Kelautan dan Perikanan, maka visi Balai Perikanan Budidaya Air Payau (BPBAP) Situbondo tahun 2014 adalah Balai Perikanan Budidaya Air Payau Situbondo sebagai institusi rujukan teknologi perikanan budidaya adaptif dalam pengembangan kawasan minapolitan sebagai sumber pertumbuhan ekonomi andalan. Balai Perikanan Budidaya Air Payau (BPBAP) Situbondo, Jawa Timur merupakan salah satu balai yang mengkaji kultur fitoplankton salah satunya yaitu Chlorella sp..

\section{Teknik Kultur Chlorella sp. Skala Laboratorium \\ Persiapan Alat dan Bahan}

Alat dan bahan yang digunakan pada kegiatan kultur Chlorella sp. skala laboratorium terdiri dari air dan berbagai peralatan kaca dan plastik. Peralatan kaca yang dipakai seperti Erlenmeyer, peralatan plastik seperti carboy. Tahap awal dalam kultur Chlorella sp. skala laboratorium yaitu sterilisasi alat dan bahan yang bertujuan untuk membunuh mikroorganisme yang tidak diinginkan (Cahyaningsih, et al., 2009). Sterilisasi alat dilakukan menggunakan oven, sedangkan sterilisasi air menggunakan autoclave. Bahan yang dibutuhkan untuk proses kultur Chlorella sp. yaitu pupuk Walne dan vitamin. Kultur skala laboratorium dilakukan dalam dua tahap yaitu kultur Chlorella sp. Murni I dan Murni II.

\section{Kultur Chlorella sp. Murni I}

Kultur Chlorella sp. murni I diawali dengan kultur fitoplankton dari perairan bebas (alam) atau bisa juga dari kultur monospesies. Alat yang digunakan yaitu Petridisk, test tube, Erlenmeyer 250 $\mathrm{ml}$, Erlenmeyer $1000 \mathrm{ml}$, lampu Bunsen, dan jarum ose. Kultur awal dilakukan dengan pembuatan media padat dengan cara mengautoclave 1 liter air laut yang telah disaring kemudian diberi pupuk $1 \mathrm{ml}$ tanpa vitamin. Air laut kemudian diambil $100 \mathrm{ml}$ air dan menambahkan bakto agar 1,5 - 2 gram dipanaskan dengan bunsen di bawah kaki tiga ataupun dengan steam dan disterilkan. Media dikeluarkan dari steam dan diberi 2 tetes vitamin $(0,1 \mathrm{ml})$. Media dituang ke petridisk setelah suhu $26-34^{\circ} \mathrm{C}$ sebanyak $3 / 4$ bagian $(4 \mathrm{ml})$ dan ditutup. Media diberi bibit sebanyak 20-30\% dari volume kultur, dan dibiarkan 1-2 hari. Setelah 2-3 minggu Chlorella akan tumbuh berupa titik-titik dan setelah 1 bulan akan tumbuh berwarna hijau.

Pada kultur di test tube, aquades steril diberi vitamin kemudian dituang ke test tube $3 / 4$ bagian (volume $15 \mathrm{ml}$ ). Bibit diambil dari Petridisk dengan jumlah koloni sesuai dengan keinginan. Kultur mengalami puncaknya paling cepat pada umur 1 minggu. Setiap 2 minggu sekali Chlorella sp. dikocok agar tidak mengendap. Menurut Cahyaningsih (2009), selama masa kultur stok bibit dala test tube harus dikocok setiap hari dengan tujuan untuk menghindari terjadinya pengendapan fitoplankton dan difusi udara untuk meningkatkan kelarutan CO2. Kemudian Kultur pada Erlenmeyer dilakukan menggunakan Erlenmeyer $250 \mathrm{ml}$. Bibit diambil dari test tube dengan perbandingan antara bibit dan air laut yaitu 3:7. Bibit dari Erlenmeyer ini nantinya akan digunakan untuk kultur pada Bottle glass.

\section{Kultur Chlorella sp. Murni II}

Kultur Chlorella sp. murni II adalah kegiatan kultur Chlorella sp. dalam skala laboratorium menggunakan bottle glass (2,5 liter) dan carboy (7,5 liter). 
Starter (bibit) yang digunakan diperoleh dari kultur murni I. Sumber cahaya untuk kegiatan kultur murni II diperoleh dari lampu TL 10 watt dengan intensitas cahaya sebesar 3000 Lux dan selama proses pemeliharaannya diberi aerasi. Kepadatan awal bibit Chlorella sp. untuk kultur di bottle glass yaitu $450.000 \mathrm{sel} / \mathrm{ml}$, suhu awalnya $23^{\circ} \mathrm{C}$, dan salinitasnya 35 ppt. Kepadatan awal bibit Chlorella sp. untuk kultur di carboy yaitu 480.000 $\mathrm{sel} / \mathrm{ml}$, suhu awal $23^{\circ} \mathrm{C}$, dan salinitasnya yaitu 35 ppt.

\section{Teknik Kultur Chlorella sp. Skala Intermediet \\ Sterilisasi Alat dan Wadah Kultur}

Sterilisasi peralatan kultur yaitu selang aerasi, pemberat, dan batu aerasi dilakukan dengan merendam di dalam kaporit 5 ppm selama 24 jam. Setelah itu alat dicuci dengan deterjen, dibilas dengan air tawar dan dikeringkan. Sterilisasi bak kultur dilakukan dengan mencuci bak dengan deterjen dan menggosok dindingdindingnya hingga bersih dan dibilas dengan air tawar mengalir. Bak yang sudah bersih dibiarkan terlebih dulu agar terkena sinar matahari sampai ke dasar bak dan dinding bak kering. Dinding bak yang sudah bersih disiram dengan kaporit 5-10 ppm hingga merata dan dibiarkan selama 24 jam. Setelah kering, dinding bak berkaporit digosok hingga bersih kemudian dibilas dengan air.

\section{Sterilisasi Media Kultur}

Bak kultur diisi dengan air laut dengan volume kurang lebih 450 liter. Air di bak diberi kaporit 5-10 ppm dan dibiarkan selama 24 jam. Pengisian air dan pemberian kaporit pada media kultur dilakukan pada siang hari, hal ini bertujuan untuk mensterilkan kandungan air yang akan digunakan untuk kultur pada esok harinya, hal ini disebabkan karena sinar matahari dapat mempercepat proses penguapan kaporit disamping pengaruh aerasi (Prayogo dan Miftahol, 2015). Ketika akan digunakan air diberi natrium thiosulfat 5-10 ppm, didiamkan selama 30 menit, kemudian diperiksa kenetralan dengan chlorine test.

\section{Pemberian Bibit Chlorella sp.}

Bibit yang digunakan untuk kegiatan kultur Chlorella sp. skala intermediet diperoleh dari kultur skala laboratorium dalam carboy yang bervolume 7,5 L. Biomassa Chlorella sp. yang bagus untuk dijadikan bibit dalam kultur skala intermediet adalah bibit yang dipanen pada fase puncak eksponensial (Creswell, 2010). Bibit yang dikultur dari fase eksponensial puncak adalah bibit yang sedang mengalami pertumbuhan maksimal dan kepadatannya juga maksimal, sehingga apabila sel ini dikultur dalam skala yang lebih besar, sel Chlorella sp. akan berkembang lebih cepat. Kepadatan awal Chlorella sp. di bak kultur intermediet yaitu $60.000 \mathrm{sel} / \mathrm{ml}$.

\section{Pemeliharaan Chlorella sp. Skala Intermediet \\ Pengukuran Kualitas Air}

Chlorella sp. tumbuh baik pada suhu $20^{\circ} \mathrm{C}$, tetapi tumbuh lambat pada suhu $32^{\circ} \mathrm{C}$. Kisaran suhu untuk partumbuhan Chlorella sp. yaitu pada suhu antara $25-30^{\circ}$ C. (Isnansetyo dan Kurniastuty, 1995). Sesuai dengan pernyataan tersebut, suhu kultur skala intermediet ini yaitu $27^{0} \mathrm{C}$, ini termasuk dalam kisaran suhu optimum.

Chlorella sp. tumbuh pada salinitas 25 ppt. Chlorella air laut dapat mentolerir salinitas antara 33-40 ppt. Chlorella sp. tumbuh lambat pada salinitas $15 \mathrm{ppm}$, dan hampir tidak tumbuh pada salinitas $0 \mathrm{ppm}$ dan 60 ppm (Isnansetyo dan Kurniastuty, 1995). Dari pertanyaan ini bila disbandingkan dengan data pengukuran kualitas air menunjukkan bahwa Chlorella sp. memiliki kemampuan tahan terhadap rentan salinitas yang tinggi. Chlorella masih bisa hidup pada salinitas $37 \mathrm{ppt}$.

$\mathrm{pH}$ merupakan salah satu faktor yang sangat penting bagi kehidupan organisme air termasuk Chlorella sp.. Nilai $\mathrm{pH}$ 
berkaitan dengan ketersediaan unsur hara bagi Chlorella sp.. Pengukuran $\mathrm{pH}$ dilakukan 4 hari sekali. Hasil pengukuran nilai $\mathrm{pH}$ kultur Chlorella sp. skala intermediet menunjukkan nilai rata-rata 8,20, nilai ini merupakan $\mathrm{pH}$ optimum untuk pertumbuhan Chlorella sp. yaitu antara 7 sampai 9 (Effendi, 2003).

Oksigen terlarut (DO) adalah jumlah oksigen dalam milligram yang terdapat dalam $1 \mathrm{~L}$ air atau ppt. DO berasal dari difusi udara melalui permukaan air dan proses fotosintesis mikroalga Chlorella sp. itu sendiri. Konsentrasi oksigen terlarut adalah parameter penting dalam menentukan kualitas perairan. DO diukur menggunakan DO meter, dan pengukuran dilakukan seminggu sekali karena keterbatasan alat ukur di Laboratorium Pakan Alami. Nilai DO pada kultur Chlorella sp. di kultur skala intermediet adalah $6,19 \mathrm{mg} / \mathrm{l}$.

\section{Penghitungan Kepadatan Sel Chlorella sp.}

Penghitungan kepadatan Chlorella sp. dilakukan menggunakan haemocytometer. Penghitungan kepadatan Chlorella sp. menggunakan metode big block, hal ini dikarenakan ukuran Chlorella sp. yang lebih besar dari $6 \mu \mathrm{m}$, yaitu 2-12 $\mu \mathrm{m}$ dan jumlah sel tidak terlalu padat. Penghitungan jumlah kepadatan sel Chlorella sp. dilakukan untuk mengetahui jumlah sel dan peningkatan sel Chlorella sp. agar memudahkan waktu pemanenan.

Berdasarkan hasil penghitungan kepadatan Chlorella sp. dapat diketahui bahwa fase lag (adaptasi) terjadi pada hari ke-0 sampai hari ke-3. Hal ini dikarenakan pada hari tersebut masih terjadi penyesuaian terhadap lingkungan namun jumlah sel meningkat sedikit demi sedikit. Fitoplankton Chlorella sp. belum terlalu memanfaatkan nutrien untuk pertumbuhan. Fase logaritmik (eksponensial) terjadi pada pengamatan ke-4 sampai pengamatan ke-6. Hal ini dikarenakan pada fase ini terjadi peningkatan jumlah sel secara konstan dengan kandungan nutrien yang masih tinggi.

Fase stasioner pada kultur ini tidak diamati karena Chlorella sp. harus dipanen pada fase eksponensial dimana sel mengalami puncak pertumbuhan. Sedangkan menurut Fadilla (2010) fase stasioner terjadi pada hari ke-5 dimana adanya penghentian pertumbuhan sel secara total atau adanya keseimbangan antara tingkat pertumbuhan dan tingkat kematian. Fase stasioner terjadi karena organisme telah memanfaatkan nutrien yang berasal dari pupuk secara optimum untuk pertumbuhan (Subekti, 2010). Fase kematian terjadi pada hari ke-6 sampai hari ke-7 yang ditandai dengan laju kematian Chlorella sp. lebih cepat dibandingkan laju pertumbuhannya, sehingga terjadi penurunan jumlah kepadatan sel (Putra et al., 2014).

\section{Pemanenan Chlorella sp.}

Berdasarkan kurva pertumbuhan Chlorella sp. waktu yang tepat untuk pemanenan yaitu pada pertengahan fase eksponensial. Hal ini dikarenakan fase eksponensial memiliki ketersediaan nutrien dalam media kultivasi masih mencukupi untuk terjadinya pertumbuhan. Selain ketersediaan nutrien, pada fase eksponensial aktivitas pertumbuhan sel Chlorella sp. dalam keadaan paling optimal (Kurniawan dan Aunurohim, 2013; Suantika dan Hendrawandi, 2008; Zulaika dan Widi, 2014 dalam Selvika, dkk., 2016). Pemanenan Chlorella sp. dilakukan pada hari ke-6 dengan kepadatan sel mencapai $797.500 \mathrm{sel} / \mathrm{ml}$. Pada hari ke-6 ini Chlorella sp. telah berada pada fase eksponensial.

Pemanenan Chlorella sp. untuk skala intermediet di BPBAP dilakukan dengan pemindahan Chlorella sp. dari bak kultur intermediet ke dalam bak kultur skala massal. Kultur skala massal dilakukan dengan volume air lebih dari 1 ton. Kultur skala massal ini selanjutnya dipanen untuk dijadikan sebagai pakan alami larva ikan laut. Pemanenan Chlorella sp. selain untuk bibit kultur skala massal juga 
dipanen untuk pembuatan powder Chlorella sp.. Pemanenan ini dilakukan dengan menggunakan metode flokulan kimia.

\section{Kendala dan Upaya Penanggulangan dalam Kultur Chlorella sp.}

Kendala yang terdapat dalam teknik kultur Chlorella sp. adalah media kultur yang tidak bebas dari kontaminan, kepadatan awal yang tidak optimal, dan kondisi lingkungan yang tidak baik. Kontaminasi biologi seperti kontaminasi oleh protozoa dapat diminimalisir dengan cara melakukan sterilisasi semua peralatan, bahan, dan media kultur yang akan digunakan sesuai dengan standar operasional prosedur (SOP). Kondisi lingkungan yang tidak baik seperti kualitas air yang tidak sesuai dengan habitat Chlorella sp. dan kondisi cuaca yang fluktuatif akibat musim pancaroba yang mempengaruhi intensitas cahaya pada kultur Chlorella sp. skala intermediet. Kondisi kualitas air yang tidak baik dapat ditanggulangi dengan dilakukan monitoring setiap hari agar kondisi lingkungan selalu dalam kondisi terkontrol.

\section{KESIMPULAN DAN SARAN Kesimpulan}

Kesimpulan yang diperoleh berdasarkan kegiatan Praktek Kerja Lapang (PKL) di Laboratorium Pakan Alami BPBAP Situbondo yaitu kultur Chlorella sp. skala laboratorium dimulai dari isolasi Chlorella sp. dari alam pada Petridisk (media agar) dilanjutkan ke test tube $10 \mathrm{ml}$ kemudian pada Erlenmeyer $500 \mathrm{ml}$. Kultur dari Erlenmeyer dilanjutkan ke bottle glass dan dilanjutkan lagi ke carboy. Kultur skala intermediet dilakukan dengan penanaman Chlorella sp. dari carboy 10 liter ke fiber glass 500 liter. Pemanenan dengan pemindahan bibit dari skala intermediet ke bak kultur skala massal untuk pakan larva ikan kerapu cantik dan juga dilakukan pemanenan dengan metode flokulan kimia menggunakan $\mathrm{NaOH}$ untuk dibuat powder Chlorella sp. Kendala yang terdapat dalam teknik kultur Chlorella sp. adalah media kultur yang tidak bebas dari kontaminan, kepadatan awal yang tidak optimal, dan kondisi lingkungan yang tidak baik (kualitas air dan kondisi cuaca).

\section{Saran}

Pelaksanaan kultur Chlorella sp. diperlukan pengamatan fase-fase pertumbuhan Chlorella sp. setiap hari, agar tidak terdapat bibit yang kurang baik saat digunakan untuk kultur skala intermediet sehingga dapat menentukan waktu panen yang tepat (berada pada fase eksponensial).

\section{DAFTAR PUSTAKA}

Cahyaningsih, S., A.N.M. Muchtar, S.J. Purnomo., I. Kusumaningrum, P. A. Haryono, Slamet dan Asniar. 2009. Juknis Produksi Pakan Alami. Departemen Kelautan dan Perikanan Direktorat Jenderal Perikanan Budidaya Balai Air Payau Situbondo. 35 hal.

Chilmawati, D. dan Suminto. 2008. Penggunaan Media Kultur yang Berbeda terhadap Pertumbuhan Chlorella sp.. Fakultas Perikanan dan kelautan. Universitas Diponegoro. Jurnal Saintek Perikanan. 4 (1) : 42 - 49

Creswell., L. 2010. Phytoplankton Culture for Aquaculture Feed. Southern Regional Aquaculture Center. United States.

Effendi H. 2003. Telaah Kualitas Air Bagi Pengelolaan Sumberdaya dan Lingkungan Perairan, Yogyakarta.

Fadilla, Z. 2010. Pengaruh konsentrasi limbah cair tahu terhadap pertumbuhan mikroalga Scenedesmus sp. Skripsi. Fakultas Sains dan teknologi. Universitas Islam Negeri Syarif Hidayatullah. Jakarta.

Isnansetyo A. dan Kurniastuty. 1995, Teknik Kultur Phytoplankton Zooplankton. Pakan Alam untuk pembenihan organism laut. Kanisius, Yokyakarta. 
Kurniawan, J. I. dan Aunurohim. 2013. Biosorpsi logam $\mathrm{Zn} 2+$ dan $\mathrm{Pb} 2+$ oleh mikroalga Chlorella sp. Jurnal Sains dan Seni Pomits, 3(1): 23373520 .

Prayogo, I. dan A. Mftahol. 2015. Teknik Kultur Pakan Alami Chlorella sp. dan Rotifera sp. Skala Massal dan Manajemen Pemberian Pakan Alami pada Larva Kerapu Cantang. Samakia: Jurnal Ilmu Perikanan. Volume 6 No. 2

Putra, I. K. R., D. Anggreni dan I. W. Arnata. 2014. Pengaruh jenis media terhadap konsentrasi biomassa dan klorofil mikroalga Tetraselmis chuii. Fakultas Teknologi Pertanian. Universitas Udayana, Bali.

Rachmaniah , O., R. D. Setyarini dan L. Maulida. 2010. Pemilihan Metode Ekstraksi Minyak Alga dari Chlorella sp. dan Prediksinya sebagai Biodiesel. Seminar Teknik Kimia Soehadi Reksowardojo 2010. Fakultas Teknologi Industri. Institut Teknologi Sepuluh Nopember. Surabaya. 10 hal.

Rismiarti, A., P. K. Hermin., Z. Muhammad., P. Sri. 2016. Karakterisasi dan Identifikasi Molekuler Fusan Hasil Fusi Protoplas Interspesies Chlorella pyrenoidosa dan Chlorella vulgaris Menggunakan 18SrDNA. Fakultas Perikanan dan Ilmu Kelautan. Universitas Diponegoro. Bioma 1 (1): 30-40

Sari, I. P dan A. Manan. 2012. Pola pertumbuhan Nannochloropsis oculata pada skala laboratorium, intermediet dan masal. Ilmiah Perikanan dan Kelautan. 4(2) : 123127.

Selvika, Z., B. J. Aradea., N. Ervina., B. F. S. P. Negara. 2016. Pertumbuhan Chlorella sp. pada beberapa konsentrasi limbah batubara. Program Studi Ilmu Kelautan, Fakultas Pertanian, Universitas Bengkulu, Bengkulu. Depik, 5(3): 107-112.
Suantika, G., D. Hendrawandi. 2008. Efektivitas teknik kultur menggunakan sistem kultur statis, semikontinyu dan kontinyu terhadap produktivitas dan kualitas kultur Spirulina sp. Jurnal Matematika dan Sains, 14(2): 41-50.

Subekti, D. A., P. Sukardi, T. Winanto. 2010. Pengaruh berbagai komposisi tingkat konsentrasi media pupuk urea terhadap kandungan glukosa Nannochloropsis sp. sebagai alternatif bahan baku bioetanol. Jurusan Perikanan dan Kelautan Fakultas Sains dan Teknik. Universitas Jenderal Soedirman, Purwokerto.

Zulaika, E. dan R. Widi. 2014. Resistensi Chlorella sp. dan potensinya sebagai bioakumulator kadmium. Jurusan Biologi. FMIPA, Institut Teknologi Sepuluh November. Surabaya. 